BY THE

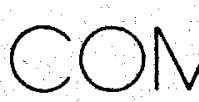

MPTROLLER

GENERAL

Chairman, Subcommittee On Energy And

Power, Committee On Interstate And Foreign

Commerce, House Of Representatives

OF

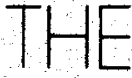

UNITED ST

STATES

\title{
The Geothermal Loan Guarantee Program: Need For Improvements
}

The geothermal loan guarantee program has been only partly successful in accelerating the development of geothermal energy. Loan guarantees have been made for only four projects since the program's enactment in 1974 and the goal to establish normal borrower-lender relationships probably will not be met when authorizing legislation is scheduled to expire in 1984. Technical and economic uncertainties, as well as management problems, have limited progress.

However, the Department of Energy can improve the program by

-developing and implementing a welldefined comprehensive strategy and

-streamlining its project review and selection procedures.

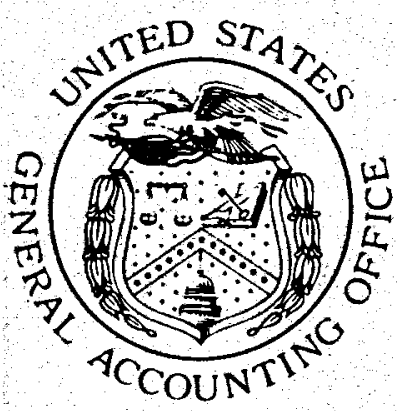




\section{DISCLAIMER}

This report was prepared as an account of work sponsored by an agency of the United States Government. Neither the United States Government nor any agency Thereof, nor any of their employees, makes any warranty, express or implied, or assumes any legal liability or responsibility for the accuracy, completeness, or usefulness of any information, apparatus, product, or process disclosed, or represents that its use would not infringe privately owned rights. Reference herein to any specific commercial product, process, or service by trade name, trademark, manufacturer, or otherwise does not necessarily constitute or imply its endorsement, recommendation, or favoring by the United States Government or any agency thereof. The views and opinions of authors expressed herein do not necessarily state or reflect those of the United States Government or any agency thereof. 


\section{DISCLAIMER}

Portions of this document may be illegible in electronic image products. Images are produced from the best available original document. 
$B-197340$

The Honorable John D. Dingell

Chairman, Subcommittee on

Energy and Power

Committee on Interstate and

Foreign Commerce

House of Representatives

Dear Mr. Chairman:

As requested in your letter of March 12, 1979, and in subsequent discussions with your office, this report discusses the progress and management of the Department of Energy's geothermal loan guarantee program. It contains recommendations for improving the program and matters for consideration by the Congress.

As arranged with your office, unless you announce its contents earlier, we plan no further distribution until 7 days from the date of the report. At that time we will send copies to interested parties and make copies available to others upon request.

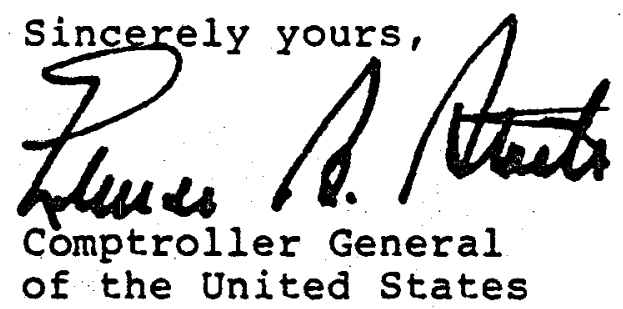


COMPTROLLER GENERAL'S REPORT TO

THE CHAIRMAN, SUBCOMMITTEE ON

ENERGY AND POWER, HOUSE COMMITTEE

ON INTERSTATE AND FOREIGN COMMERCE
THE GEOTHERMAL LOAN GUARANTEE PROGRAM : NEED FOR IMPROVEMENTS

\section{$\underline{D} \underline{\mathbf{I}} \underline{\mathrm{E}} \underline{\mathrm{S}} \underline{\mathrm{T}}$}

The geothermal loan guarantee program whose purpose is to encourage and assist commercial development of useful energy from geothermal resources has had only limited effect on accelerating geothermal energy development. The Department of Energy has approved only four projects since the program's enactment in 1974. (See p. 3.)

One reason for limited progress is the technical and economic uncertainties of developing geothermal resources. (See p. 3.) However, factors directly related to the program have also contributed to slow progress. (See p. 6.)

Increasea availability of venture capital, better market conditions, and gains in technology should have a positive effect on the program's ability to attract more and better projects. (See p. 8.)

A number of management problems have served to limit the program's effectiveness. The Department of Energy has never developed and implemented a comprehensive strategy for the geothermal loan guarantee program. As a result, it is highly unlikely that the program will meet its objectives, particularly its goal to establish normal borrower-lender relationships when the program's legislation expires in 1984. In fact, the Department's high degree of project involvement runs counter to achieving this goal. Further, the lack of a well-defined strategy has also resulted in reactive decisionmaking and the selection of projects not meeting the program's highest prlority needs. (See p. 11.)

The program has also been plagued by administrative delays due to redundant review and selection procedures, which may have 
discouraged potential applicants who might otherwise have participated in the program. Other delays, including decisions on the use of the Federal Financing Bank and interest differential payments have resulted from the Department's failure to settle unresolved policy issues in a timely manner: (See p. 11.)

\section{RECOMMENDATIONS}

To provide clearer direction for the geothermal loan guarantee program and greater assurance that the program meets its primary objective and goal, the secretary of Energy should develop and implement a comprehensive strategy. As a minimum, the strategy should include

--amendments to regulations and any other mechanisms that may be needed to allow lenders to assume greater responsibility for project administration and monitoring, thereby minimizing Government involvement;

--project selection factors in terms of geographical area, project type, project size, technical innovation, and borrower category;

-ways to solicit industry involvement and to seek out and select projects that best meet program needs; and

--means to evaluate program progress and to modify program activities as circumstances change. (See p. 24.)

To ensure that further administrative delays do not occur, the secretary should take immediate action to ensure that regulations are issued in a timely manner and to streamline project selection and milestone review procedures. Further, the secretary should delegate authority to the Department's San Francisco Operations office Manager to approve projects within an established ceiling and to approve restructured milestones when they conform to basic project objectives. 
To ensure that the program is achieving maximum participation, the secretary should vigorously pursue resolution of the interrelated questions on the use of the Federal Financing Bank and interest differential payments with the office of Management and Budget and the Department of the Treasury. (See p. 25.)

MATTTERS FOR CONSIDERATION BY THE CONGRESS

The Congress will most 1 ikely be continually faced with requests for additional loan guarantee authority and funding for the geothermal loan guarantee program. In considering (1) the present adequacy of support for this program and (2) the uncertainty of the program's ability to meet its objectives by its 1984 expiration date, the Congress should be mindful that the program lacks a comprehensive strategy for attaining its objectives. In this connection, GAO is recommending that the Department develop and implement such a strategy which should be useful in determining how additional funds will help the development and commercialization of geothermal energy most effectively. Before further authorizations are approved, the Congress may wish to require the Department of Energy to submit the strategy as part of its budgetary process, or as an addendum to any legislative proposals for the program.

The congress should recognize that the $25-$ percent equity requirement is an impediment. to small geothermal users/producers using the program. The Congress may want to provide the Department of Energy authority to relax this requirement for small projects on either a case-by-case basis or reduce the equity requirement for all small business applicants. In this regard, several bills have been introduced in the $96 \mathrm{th}$ Congress which would reduce the 25-percent. equity requirement for small businesses to 10 percent. (See p. 25.) 


\section{AGENCY COMMENTS}

GAO obtained comments from the Department of Energy. (See app. IV.) The Department stated that the report was constructive and provided comments that it believed would clarify or more fully explain several of the issues raised. These comments and GAO's evaluation are presented beginning on page 26 .

The Office of Management and Budget and the Department of the Treasury did not provide written comments but instead provided informal comments. Both agencies provided information only on the issue relating to the use of the Federal Fihancing Bank. (See p. 28.)

\section{RECENT DEPARTMENT OF ENERGY ACTIONS}

While GAO was preparing its final report for publication, the Department of Energy issued on December 18, 1979, revised geothermal loan guarantee regulations. The revised regulations provide increased priority to loan guarantee applications for projects in undeveloped geothermal resource areas, set forth criteria for loan funding through the Federal Financing Bank, and provide for the payment of interest differential assistance.

GAO believes that these actions should help the program. However, final resolution of the Federal Financing Bank and interest differential payments issues will only be accomplished if the revised regulations are implemented in a timely and effective manner. The cooperation of the office of Management. and Budget, and the Departments of the Treasury and Energy will be needed for the implementation process to be timely and effective. 
OTHER GAO REPORT

ON GEOTHERMAL ENERGY

A discussion of other Federal geothermal energy development programs and of the obstacles and uncertainties impeding the widespread use of geothermal resources is contained in our report entitled, "Geothermal Energy: Obstacles and Uncertainties Impede its Widespread Use" (EMD-80-36, January 18,1980$)$. 


\section{DIGEST}

\section{CHAPTER}

INTRODUCTION

Purpose of study

Scope of review

2

THE GEOTHERMAL LOAN GUARANTEE PROGRAM

HAS MADE LIMITED PROGRESS

1

2

2

Limited participation in the program

Indications of greater participation in the loan guarantee program

Ultimate program success depends on improvements being made.

WAYS TO IMPROVE THE GEOTHERMAL LOAN

GUARANTEE PROGRAM

Need to develop and implement a comprehensive strategy

Need to streamline project review and selection procedures

Need to resolve major policy issues

CONCLUSIONS, RECOMMENDATIONS, MATTERS FOR

CONSIDERATION BY THE CONGRESS, AND AGENCY COMMENTS AND OUR EVALUATION

Conclusions

Recommendations to the Secretary of Energy

Matters for consideration by the Congress

Agency comments and our evaluation

APPENDIX 


\section{APPENDIX}

I I I

Letter dated March 12, 1979, from the Chairman, Subcommittee on Energy and Power, House Committee on Interstate and Foreign Commerce

IV

Letter dated December 11, 1979, from the Department of Energy, commenting on this report.

\section{ABBREVIATIONS}

DOE

ERDA

FFB

GAO

GFP

GLGP

IRS

OMB

Department of Energy

SAN

Energy Research and Development Administration Federal Financing Bank

General Accounting Office

Geothermal Food Processors, Inc.

Geothermal Loan Guarantee Program

Internal Revenue Service

Office of Management and Budget

San Francisco Operations Office 


\section{CHAPTER 1}

\section{INTRODUCTION}

Geothermal resources are sources of natural heat in the Earth. Where concentrated near the Earth's surface, energy from these resources in the form of hot water or steam can be extracted to produce electricity or be used for direct heating. In order to provide an integrated effort and commitment for effectively developing geothermal energy resources, the Congress enacted the Geothermal Energy Research, Development, and Demonstration Act of 1974 (P.L. 93-410, Sept. 3, 1974). In part, the act established the geothermal loan guarantee program and a Geothermal Resources Development Fund to support loan guarantees and pay program administrative expenses.

The purpose of the loan guarantee program as stated in the act is to encourage and assist the commercial development of practical means to produce useful energy from geothermal resources. Another purpose, added to the program's implementing regulations by the administration, is to develop normal borrower-lender relationships which will in time encourage the flow of credit to assist geothermal development without the need for Federal assistance.

The geothermal loan guarantee program is managed under the direction of the Department of Energy's (DOE's) Assistant Secretary for Resource Applications. Because most geothermal resources expected to be developed by 1985 are located in the western half of the United States, the Manager of DOE's San Francisco Operations office (SAN) has been delegated national operational authority for the program. Under this delegation, the Manager accepts, evaluates, and recommends approval of project applications based on priorities DOE has developed for the selection of projects; monitors project status; and coordinates activity in default situations. Final project approval authority rests with the Assistant Secretary for Resource Applications.

The 1974 act requires that, to be eligible for the program, borrowers must be able to provide an equity investment of at least 25 percent of total project costs. The Federal guarantee applies to the remaining 75 percent supplied by an approved lender.

PÜRPOSE OF STUDY

On March 12, 1979, the Chairman of the subcommittee on Energy and Power, House Committee on Interstate and Foreign 
Commerce, asked that we review the activities of the guarantee program.

In response to that request, this report addresses

- - the current status of the program, including a review. of the progress being made and problems encountered;

--the effectiveness of DOE's management of the program; and

--specific questions concerning alleged improprieties relating to individual loan guarantee projects.

A discussion of the status of individual loan guarantee projects is included as appendix I. Answers to the specific project questions asked by the Chairman are included in appendix II. A copy of the Chairman's request is included as appendix III.

\section{SCOPE ÓE. RÉVIIÉW}

We conducted our review primarily at the DOE headquarters in Washington, D.C., and at SAN. We also obtained information from the Department of the Treasury and the office of Management and Budget in Washington, D. C. We interviewed private industry representatives, representatives of financial lending institutions, and state and public utility officials involved in geothermal development, and visited geothermal resource projects with guaranteed loans. We examined Federal, state, and privately financed studies and documents.

Our report deals with the geothermal loan guarantee program which is only one of several Federal research, development, demonstration, and leasing activities aimed at assisting the commercial development of geothermal energy. A discussion of the Federal role in developing geothermal energy and the obstacles and uncertainties impeding the widespread use of geothermal resources is contained in our report entitled, "Geothermal Energy: Obstacles and Uncertainties Impede its Widespread Use" (EMD-80-36, January 18,1980 ). 


\section{CHAPTER 2}

\section{THE GEOTHERMAL LOAN GUARANTEE}

\section{PROGRAM HAS MADE LIMITED PROGRESS}

To date, the geothermal loan guarantee program has had only limited participation and effect on accelerating geothermal development. The technical and economic obstacles and uncertainties of developing geothermal resources, in general, have been largely responsible for the limited progress.

\section{LIMITED PARTICIPATION IN}

\section{$\overline{\mathrm{T}} \overline{\mathrm{H}} \overline{\mathrm{P}} \overline{\mathrm{P}} \overline{\mathrm{R}} \overline{\mathrm{G}} \overline{\mathrm{R}} \overline{\mathrm{A}} \overline{\mathrm{M}}$}

To date, participation in the program has been less than originally anticipated. In this connection, the act estab1 ished the program as a tool to help accelerate geothermal development and use. However, during the program's 5-year existence, DOE has received 14 applications, of which only 4 have been processed and approved, 5 are pending action, and 5 have been returned without approval. Two of the five pending applications are "on hold" and will probably not be approved as presently submitted. The four approved projects are as follows:

Name/Location

East Mesa, Imperial Valley, Calif.

Geothermal Food Processors, Brady Hot Springs, Nev.

CU-1, Brawley, Calif: (Imperial Valley)

Westmorland, Imperial valley, Calif.

Type Guarantee amount (in milions)

field development (electric)

vegetable dehydration plant
$\$ 9.0$

3.5

1.8

exploration (electric) exploration and

field development (electric)

Total

$\$ 43.4$

Although participation in the program has been limited, project borrowers and DOE officials pointed out that these four projects would not have been started as early as they did without the program. 
Geothermal development, in general, has been slow

One reason for Iimited program participation is that geothermal resource development, generally, and geothermal electrical power generation, particularly, is not moving very guickly. The trend of geothermal's estimated electric potential, as shown by the periodic forecasts in the following table, indicates that geothermal energy will not be developed as early as initially expected.

Forecast Estimated electric potential

Year from geothermal sources by (in thousands of megawatts)

General forecasts (note a)

1975

8 to 35 30 to 700

Energy Research and

3 to 4 20 to 40 Development Administration (ERDA) (note b) DOE

a /Forecasts by the National science Foundation, Jet Propulsion Laboratory, and ERDA.

b/Prior to the establishment of DOE on October 1,1977 , ERDA-which was absorbed by DOE-had responsibility for the program. For the sake of reporting convenience, hereafter, this report uses DOE even when referring to the former ERDA.

Our review indicated that the 1979 forecast may be optimistic. Currently only 665 megawatts of electrical power are being produced from geothermal energy, all at one location. Based on projects initiated and committed to date, we believe it is unlikely that even 3,000 megawatts will be on-line by 1985 .

\section{Reasons for slow progress}

The most basic reasons explaining why the geothermal industry has so far not matured are the nature of geothermal energy and its potential market.

Geothermal energy from a practical standpoint cannot be stored and is not transportable over great distances. Thus, facilities for direct use and electric power generation must be 
co-located with the resource. It is imperative, therefore, that the geothermal reservoir be capable of producing the same quality energy resource over the amortized life of the facilities. For electrical generation plants, this could be as long as 25 to 30 years. However, techniques to evaluate geothermal reservoir life have not been developed to the point where commercial lenders and other financial institutions have sufficient assurance that the plant will remain viable, thereby justifying a long-term loan for financing the plant.

Every geothermal resource is different, and technological problems are therefore unique. Geothermal reservoirs exhibit different temperatures, pressures, and chemical impurities. Furthermore, geothermal development, especially for electrical projects, is highly capital intensive. At present, a geothermal powerplant in a proven field requires a minimum investment of about $\$ 50$ to $\$ 60$ million, which includes developing a resource field of about 18 to 20 wells. Further, projects require long lead times ( 7 to 10 years) before revenues are generated.

Until the 1973-74 Arab oil embargo, commercial electricity from geothermal resources was 1 imited to the Geysers, a northern California "dry steam" field that produces electrical power at a price competitive with fossil fuels. The Geysers is now producing 665 megawatts of electricity and is the largest producing geothermal field in the world. Unfortunately. the bulk of the Nation's developable geothermal reservoirs is of the "hot water" variety, which makes for greater technological problems and less efficiencies than at the Geysers. only since 1973, when fossil fuel prices increased dramatically. have these resources been considered even potentially economically feasible. However, the actual price competitiveness of "hot water" resources is st 11 an open question. The question may only be answered after commercial sized hot-water plants are built and operating.

Because of the many uncertainties associated with geothermal development, commercial lenders and other financial institutions have been hesitant to finance geothermal projects. In addition, public utilities have not been able to contribute to accelerated geothermal development. Because they are highly regulated, public utilities often cannot commit capital funds to construct powerplants on unproven geothermal reservoirs. In this regard, utilities and the financial community have generally considered reservoir areas outside the Geysers as unproven.

As a result, the high costs of powerplant construction, coupled with the uncertainties of ultimate market price, have 
so far prevented the operation of a commercial scale hot-water powerplant in the United States.

Other reasons for 1 imited participation in the program

Besides the slow growth of the geothermal industry, in general, factors directly related to the loan guarantee program have also limited participation in the program. These factors are

--its design, which attracts relatively few potential users,

- -high interest rates on loans, and

--management problems.

\section{A 1 imited number of}

\section{potential users}

The loan guarantee program is largely. limited to middlesized energy producers, often in joint ventures because of the need to raise enough capital to meet the 25-percent equity requirement. By the program's nature, both large companies and small geothermal users/producers are not attracted to the program.

Major energy companies have been reluctant to finance projects using the loan guarantee program. These companies can obtain geothermal project financing based on corporate assets. They also fear the effect a loan default would have on their public image and corporate credit ratings. Public utilities expressed to us a similar concern. They stated that even if allowed to commit funds for geothermal powerplants, they would be reluctant to do so for fear that a default would prejudice their ability to obtain future financing on the bond markets. DOE believes this concern may be more perceived than real. Nevertheless, the perception of possible credit failure, coupled with the loss of substantial investment dollars in the event of default, has so far kept large utilities from participating in the program.

Small energy producers and users have a different problem. The program's 25-percent equity requirement effectively eliminates most small projects--those under $\$ 1$ million. Such projects are normally financed by small users/producers who 
cannot meet the 25-percent equity requirement. $1 /$ Such projects are usually relatively small, simple, and short-term in nature, and are typically for direct uses of geothermal energy; examples include space heating, food processing and drying, and heating greenhouses. Thus, to make the program available for such projects, a relaxation of the 25-percent equity requirement appears necessary. In this connection, the Congress is considering legislation which would reduce the equity requirement for small businesses from 25 to 10 percent.

\section{High interest rates}

One of the reasons given by geothermal energy resource developers for not seeking DOE loan guarantees has been the high interest $r$ ates they would incur. At the time of loan closing, the four original loan rates ranged from 8 percent in May 1977 for the East Mesa project to 14.25 percent in October 1979 for the Westmorland project. Currently, interest charges are about 16 to 19 percent. Interest charges are currently so high because they were negotiated with commercial lenders whose interest charges float with the prime rate, and the 1978 and 1979 prime rates have been extremely high.

In addition, commercial lenders and DOE officials told us banks have charged rates one to three points above the prime rate for the loans made under the guarantee program because of

- - increased administrative costs associated with DOE monitoring and reporting reguirements;

--decreased lender control over the project and its loan terms due to Federal involvement in such matters as approval of loan disbursements, project milestones. and repayment schedules;

-longer than normal loan terms;

1/On the other hand, in certain instances program experience has shown that borrowers may need more equity capital than the 25-percent minimum requirement. The borrowers for the program's three electric projects have supplied equity capital in excess of the 25-percent requirement to meet unforeseen costs on these large, complex, long-term projects. 
--uncertainty over DOE's timeliness of payment in the event of default (this is DOE's first experience with loan guarantees): and

--the absence of the normal lender requirement that the borrower maintain a substantial account balance with the lender.

Some geothermal resource developers unwilling to pay these high rates have delayed projects until rates decline or they can find other financing sources.

DOE recognizes the possible impact of high interest rates on the usability of the loan guarantee program and has taken steps to obtain lower interest rates for the projects. For example, on the most recently approved project application (Westmorland), DOE officials negotiated an interest rate lower than earlier projects and lower than initially obtained by the borrower. Also, when DOE restructured the vegetable dehydration plant project after default (see app. I), the project was able to obtain a fixed long-term loan at a rate appreciably lower than the rate of the original commercial loan used for plant construction.

DOE is also considering using the Federal Financing Bank, a Federal financial intermediary between Federal agencies and the financial community, to provide lower interest $r$ ates and to serve as a back-up lender to ensure that projects are not delayed until a private lender is found.

\section{Management problems}

Management problems have persisted throughout the first 5 years of the program's life. These problems are discussed in detail in chapter 3. The program's management problems are known in the geothermal industry and among commercial lenders familiar with the program. To the extent these problems are perceived as unnecessary and destructive, they have hurt DOE's credibility and may have discouraged potential program participants from applying for support under the program.

INDICATIONS OF GREATER

PARTICIPATION IN THE

LOAN GUARANTEE PROGRAM

While participation in the geothermal loan guarantee program has so far been limited, there are indications that the program could experience increased interest over the next 3 to 5 years. Increased availability of venture capital, better market conditions, and gains in technology should have a 
positive effect on the program's ability to attract more and better projects.

The tax incentives provided by the Energy Tax Act of 1978 (P.L. 95-618, Nov. 9, 1978) are beginning to have an impact, at least for meeting resource developers yenture capital requirements. The energy producers we interviewed stated that private investors are now more willing to supply venture capital for geothermal exploration and field development projects as a result of the incentives.

Geothermal energy may be becoming increasingly more market competitive compared to other energy sources. Price increases, dwindling supplies, and serious safety and environmental questions have, to varying degrees, worked to reduce the desirability of oil, natural gas, coal, and nuclear energy. This is especially true in California where coal has typically not been used and further nuclear development is questionable.

Finally, commercial-sized projects, both within and outside the program, are making gains in advancing the technology necessary to efficiently use hot-water energy for electric and direct uses. For example, the first commercial-sized efforts to tap hot-water geothermal systems for electricity generation could be operating by the 1982-83 time frame, assuming construction proceeds on schedule. 1/ If successful, these projects should increase public utility and financial community confidence in geothermal energy and demonstrate geothermal technology on a commercial scale. The privately funded projects outside the program also demonstrate that the industry is making gains in developing financial agreements to deal with the special needs of the geothermal industry.

A noticeable increase in the number and project size of possible future loan guarantee applications supports the likelihood of greater future participation. Present applications not yet approved amount to about $\$ 69$ million in potential loan guarantees. DOE has also held preapplication discussions with six potential project applicants whose guarantee requirements, should applications be submitted and approved, would amount to another $\$ 165$ million: Follow-on guarantees to ongoing

1/Projects committed to development by the 1982-83 time frame include two privately financed 50 megawat plants in the Imperial valley of California, and a 50 megawatt demonstration plant cost-shared by DOE in New Mexico. 
projects are expected to require an estimated $\$ 175$ to $\$ 188$ million in aditional loan guarantees. I/

Through fiscal year 1980 , the program will have authority to guarantee up to $\$ 350$ million in loans. Should all of the above applications be approved, DOE would exceed the program's guarantee authority. In this regard, DOE officials told us they believe the currently authorized funds will be exhausted by the end of 1980 .

\section{ULTIMATE PROGRAM SUCCESS}

DEPENDS ON IMPROVEMENTS

BEING MADE

Al though changing circumstances point to a potential for increased participation in the geothermal loan guarantee program, we believe the degree to which this increase is actually realized will largely depend on whether DOE corrects the management problems currentiy hampering the program. In this regard, we identify and discuss, in chapter 3 , a number of ways we believe the program can be improved.

1/Follow-on projects include East Mesa full field development and plant construction, CU-1 field development, and westmorland plant construction. (See app. I.) 


\section{CHAPTER 3}

WAYS TO IMPROVE THE GEOTHERMAL

\section{LOAN GUARANTEE PROGRAM}

Although much of the limited progress in the geothermal loan guarantee program can be attributed to the technical and economic uncertainties of developing geothermal resources, a number of management problems has also served to limit the program's effectiveness. DOE has never developed and implemented a comprehensive strategy for meeting the program's primary objective of encouraging and assisting geothermal energy development and its goal of establishing normal borrower-lender relationships. As a result, and coupled with the slow growth of geothermal development, it appears highly unlikely that the program will be effective, particularly in reaching the borrower-lender goal when the authorization of the program expires in 1984. In fact, some of DOE's program activities actually run counter to achieving that goal. Also, in the absence of a comprehensive'strategy for the program, DOE's approach to selecting projects for approval under the program has been more reactive than planned in nature. The result has been the selection of projects not meeting what DOE says are the program's highest priority needs.

The program has also been plagued by administrative delays due to redundant project review and selection procedures. Such delays have frustrated borrowers and lenders in the program; and may have deterred others who might otherwise have participated.

Other delays have resulted from DOE's failure to settle unresolved policy issues in a timely manner. This failure has had the effect of putting some prospective borrowers and lenders in a "wait-and-see" position with regard to their participation in the program, and, in at least one instance, has delayed a project.

Thus, in order for the program to better meet its primary objective and the normal borrower-lender goal, improvements are needed in the program's management. These improvements include development and implementation of a comprehens ive program strategy, streamiining of project selection and milestone review procedures, and more timely settlement of unresolved policy issues. 
NEED TO DEVELOP AND IMPLEMENT

A COMPRE HENSIVE STRATEGY

DOE has never developed a comprehensive strategy for the geothermal loan guarantee program. Without clear direction, the program has been stymied in its efforts to encourage and assist geothermal energy development. As a result, DOE

-will most likely not meet the goal to normalize borrower-lender relationships by 1984 when the program is scheduled to lapse, and there is uncertainty whether the goal will be met in the foreseeable future thereafter;

- -has operated the program in ways which run counter to achieving the normal borrower-lender relationships goal; and

- -has adopted a reactive approach to project selection which results in support of projects not meeting the program's highest priority needs.

DOE will not meet its goal

of establishing normal

borrower-lender relationships

The program goal of developing normal borrower-lender relationships, which will in time encourage the flow of credit to support geothermal development without Federal assistance, will not be met by 1984 when the program expires. And it is uncertain that the goal will be met in the foreseeable period thereafter.

DOE and Treasury officials stated that the office of Management and Budget (OMB) added the normal borrower-lender relationships goal to the original geothermal loan guarantee program regulations. OMB officials told us that they believed it was important to involve the private sector in the program.

DOE and Treasury officials, as well as private lenders, borrowers, and other geothermal industry officials, told us that the program will not establish normal borrower-lender relationships by 1984 . This is because there will not be sufficient onl ine production experience by then for the financial community to have enough confidence in geothermal technology to invest without Federal guarantees. Treasury and DOE officials stated that the program may not meet this goal even in the more distant future. Based on the above comments, and the program's slow progress to date, it looks like the normal borrower-lender relationship goal will not be met in 1984 . A DOE official; for example, told us that it would take 15 to 
20 years of production experience before private sector financial institutions would invest substantially in geothermal energy development.

Certain program activities run

counter to achieving DOE's goal

to normalize borrower-lender

relationships

To ensure that the Government's interest is protected, DOE has become intricately involved in project direction. In this regard, DOE

--negotiates with lenders and approves such loan conditions as disbursement agreements, repayment schedules, and, in at least one case, interest rates;

--imposes performance standards on borrowers which are incorporated into project milestones;

--employs consultants to directly monitor project progress and evaluate milestone performance; and

--in default situations, assumes management control of projects.

We believe the high degree of DOE's involvement in projects runs counter to the program goal of establishing normal borrower-lender relationships. Many of the project administration and monitoring functions DOE is currently performing would, under normal borrower-lender circumstances, be performed by private sector financial institutions. If truly normal borrower-lender relationships are ever to be established, DOE should seek to minimize its involvement in these functions and allow lenders to assume this role.

We recognize that, early in the program's history, lender unfamiliarity with the geothermal industry made assumption of such a role difficult if not impossible. Even now, lenders may be hesitant to assume the additional administrative and monitoring effort such a role would involve. Initially, lenders may want to assume greater responsibility on a partial or case-by-case basis. Nevertheless, we believe DOE should begin now to incorporate in its comprehensive strategy specific steps designed to encourage lenders to assume greater administration and project monitoring responsibility... In addition, DOE will need to amend certain portions of its program regulations, which currently provide that DOE will perform many project administration and monitoring functions. The gradual transfer of these functions from DOE to the private sector will not only move the program in the direction of normalizing 
borrower-lender relationships, but it may also help reduce lenders' complaints of excessive DOE project control.

We recognize that the Government's interests must be protected and, to some extent, placing more project administration and monitoring responsibilities on the lenders could lessen the degree of protection DOE currently has. Therefore, in those situations where lenders assume these additional responsibilities, DOE may have to take steps to ensure continued protection of the Government's interest. To provide such assurance, we believe DOE, as a minimum, should require that lenders (1) maintain satisfactory evidence that they are performing the necessary project administration and monitoring functions and (2) grant the Government access to records so that DOE can make "spot checks" to ensure that lenders are adequately performing these functions.

Dó' 's reactive approach to project

selection results in support of

projects not meeting the program's

highest priority needs

In the absence of a carefully designed strategy to encourage and assist geothermal development through a loan guarantee program, the program has been reacting to applications as they are submitted rather than actively seeking projects which best advance the program toward attaining this primary objective. Although DOE's project selection procedures are designed to select and approve the best available projects; we noted that 3 of the 4 approved projects did not meet the program's highest priority need.

The loan guarantee program regulations in effect during our review stated that, in complying with the overall objectives of the program, DOE should give

--highest priority to projects that have a plan of operations which show promise of quickly resulting in the development of useful energy from geothermal resources,

--next priority to projects that demonstrate or use new technological advances, and

- -last priority to projects which will demonstrate or exploit the commercial potential of new geothermal resource areas.

While all four approved projects appear to use new technological advances, only one--the Geothermal Food Processors project--meets the highest program priority. The remaining 
three projects are all long-term electric projects, two of which are in the exploratory drilling stage and the third is in the initial stage of field development. Assuming that technical problems can be resolved and plant construction proceeds on schedule, these projects can be expected to have a 7 to 10 year lead time before useful energy will be produced, and therefore do not meet the program's highest priority. In addition, these projects are located in the Imperial valley of California and, therefore, exploit the commercial potential of only one new resource area. In this regard, DOE on December 18, 1979, revised its priorities for project selection to give increased priority to projects in undeveloped geothermal resource areas.

DOE officials state that they depend on the projects that come into the program to provide its direction, and that DOE has no control over the types of projects submitted by applicants. We believe, however, that the program cannot afford to rely strictly on a reactive management approach.

A comprehensive strategy could enhance DOE's project selection. The strategy should identify critical project selection factors that meet the program's priority needs in terms of geographical area, project type (electric or direct use), project size, technical innovation, borrower category, and other important factors. The strategy should also call for DOE's active involvement in seeking out and selecting projects that more closely match these criteria, thereby helping put DOE's project selection in consonance with established program priorities. In this way, for example, DOE could el iminate the situation of having the program dominated by potentially large electric projects in the same geographical area.

NEED TO STREAMLINE PROJECT REVIEW AND SELECTION PROCEDURES

During its first 5 years, the progress of the geothermal loan guarantee program has been delayed. This delay has been caused, in part, by administrative problems, which resulted from redundant project review and selection procedures. As noted in chapter 2 , these delays have frustrated borrowers and lenders in the program and, because these problems are known in the geothermal industry, they may have discouraged others from participating in the program.

We recognize DOE's inherent difficulty of trying to protect the Government's interest while attempting to accelerate geothermal development. While DOE's procedures appear adequate to protect the Government's interest, some of these procedures are redundant and have served to impede the program's progress toward accelerating geothermal development. 


\section{Administrative delays}

Administrative delays have plagued the geothermal loan guarantee program since its inception in 1974. These delays have occurred in developing and implementing regulations for the program, reviewing and approving applications for loan guarantees, and in administering the terms of the loan guarantees.

DOE has been slow to publish program regulations. Although the Geothermal Energy Research, Development, and Demonstration Act became effective on september 3, 1974, regulations to implement the program were not issued until June 25 , 1976-almost 2 years later. Since the Federal Government could not accept or process applications until implementing regulations were published, this delay resulted in the program losing almost 2 years of operating experience.

Similar problems are occurring with respect to issuing regulations to implement amendments to the act. Amendments to the loan guarantee program provisions of the Geothermal Energy Research, Development, and Demonstration Act became effective on February 25, 1978. At the time of our review, regulations had been issued implementing some, but not al1, provisions of the amendments. On December 18, 1979, DOE issued regulations implementing the remaining provisions.

Moreover, there have been substantial delays in approving applications. The time required to approve the four projects ranged from 6.5 to 21 months, as shown in the following table.

Project $\quad \begin{gathered}\text { Date } \\ \text { submitted }\end{gathered}$

East Mesa

Geothermal Food Processors

$\mathrm{CU}-1$

Westmorland

$$
\begin{aligned}
& \text { Oct. } 26,1976 \\
& \text { Mar. } 4,1977
\end{aligned}
$$$$
\text { Feb. } 28,1977
$$$$
\text { Sept. } 29,1977
$$

Date approved

\section{$\frac{\text { Total time }}{\text { in months) }}$}

One delay which particularly frustrated the borrower resulted when the CU-1 application was approved twice, once by ERDA following 7 months of review, and again by DOE, almost 4 months later. DOE officials explained that this additional approval delay was caused by the creation of DOE and the new agency's need to ensure that ERDA's projects met DOE's goals. They could not explain why the Geothermal Food Processors 
project, which ERDA approved the same day as the initial approval for the CU-1 project, was not also subjected to this additional review.

The administrative delays being incurred in the application review and approval process, and the adverse impacts of such delays on the program, have been recognized by DOE and others as a problem needing correction. For example, a March 1979 report of the Interagency Geothermal Coordinating Council 1/ underscored the problem of application approval delays. It stated:
"The time required for the review process has inhib- ited use of the loan guarantee program, especially by smaller direct thermal developers. DOE has under- gone a high degree of learning in processing the first four applications and is optimistic about re- ducing the time required to process new loan guar- antee applications. Current goals are to complete processing in no more than 4 months on the average and 6 months at the outset."

DOE officials have acknowledged the problem of the lengthy review time for loan guarantee applications, but told us that it would be impossible to process an application in 4 months. DOE recently developed and implemented a plan to shorten review time to 6 months- 4 months for field review, and 2 months for headquarters review. We believe this plan is a step in the right direction and efforts should be made to ensure that the 6-month review time guideline is met.

Administrative delays have also occurred after applications had been approved. For example, DOE has instituted procedures which tie loan disbursements to performance of project milestones. DOE contract consultants judge acceptable performance by reviewing technological, test and construction data, and may review financial, management, and market conditions as well. All this, program borrowers and lenders claim, takes time and can lead to complex re-negotiations of basic agreements especially when data are subject to interpretation: An indication of the severity of this problem was provided by one firm involved in the loan guarantee program. In a January 1979 letter to another geothermal developer, the firm stated:

1/The Council is an interagency body charged with overall responsibility to coordinate national geothermal energy research, development, and demonstration. 
* * * any deviation from the original exploration. plan seemed to be viewed by DOE as an opportunity to renegotiate the entire agreement even when the deviation was favorable to the project and the mechanism for implementing the change had already been agreed upon. Decision points in carrying out the project objectives appear to cause the greatest difficulty with DOE. Practically every milestone must be reviewed by at least one outside consultant, then by the program, legal, environmental, and senior staff of DOE San Francisco, and then by the program, legal, environmental, policy and planning, controller, and senior staff in Washington. The resulting delays in project decision. making are costly * * *."

Because borrowers must schedule and commit personnel and equipment to fit project timing, delays in receiving loan disbursements can result in increased borrower's costs as well as overall project delays. For example, a borrower has claimed that a l-month delay in receiving its second disbursement of funds cost the project about $\$ 2,100$ a day in loan interest charges and about $\$ 1,000$ a day in foregone drilling rig revenues.

DOE recognizes the problems caused by its extensive milestone review process. DOE officials, however, believe these procedures are necessary to minimize the chance of default.

Administrative delays due in part to redundant review procedures

DOE's application evaluation process actually begins before potential borrowers submit their applications to the san Francisco Operations office. SAN conducts "preapplication discussions" to answer and resolve as many questions as possible while the borrowers prepare their project applications. Once an application is submitted, it proceeds through seven review phases which evaluate the project's geothermal resource, estimated costs, and marketing, financial, management, environmental, and legal aspects. The evaluators include loan guarantee program officials and other SAN personnel, other Government agencies such as the U.S. Geological Survey, and private firms. Differences between data supplied by reviewers and that of the applicant must be reconciled before SAN submits its approval/disapproval recommendation to DOE headquarters.

DOE headguarters then conducts an application review of its own, duplicating SAN's seven review phases. "The extensive 
but redundant nature of DOE's evaluation process can be illustrated by tracing just the financial portion of an application. After SAN has gathered the necessary data on the loan terms, completed its analysis of the data, and forwarded the application package to headquarters, the geothermal loan guarantee program office at DOE headquarters then conducts its own comprehensive review of the loan terms. Controller office personnel also review the loan terms as well as the complete financial structure of the proposed project. Meanwhile, officials at the Department of the Treasury review the project's cost data and other financial aspects. In addition, under the 1974 act as amended, the secretary of the Treasury must determine that projects exceeding $\$ 25$ million will have the minimum possible impact on the capital markets of the United States.

DOE personnel, both at headquarters and at SAN, generally agreed that overlapping on the review of applications is a problem with the program.

Greater delegation of authority to DOE!s San Francisco Operations Office needed

While DOE has delegated operational oversight of projects to SAN, headquarters retains project approval authority and decisionmaking authority for matters affecting policy. However, project situations requiring DOE action do not always fall precisely into the categories of a simple operational decision or one demanding overall policy definition. Instead, many apparent operational decisions also have major policy implications. As a result, SAN personnel told us they do not always have a clear understanding of how to deal with potential applicants or existing borrowers because policies have not been defined or prioritized and because they do not have the authority to speak for the Government. While borrowers and lenders praise SAN personnel for their contributions to individual projects, they report that SAN personnel lack credibility because they cannot make decisions that take advantage of new project opportunities or make project commitments as quickly as possible.

One way DOE can improve its management of the program is by delegating greater authority to SAN, the program's operational arm. Authority to approve projects within an estab1 ished dollar ceiling, perhaps consistent with SAN's current contract and grant authority, l/ would reduce approval time

1/SAN currently has authority to approve contracts or grants up to $\$ 15$ million. 
delays by eliminating redundant headquarters review. Further, allowing SAN to approve restructured project milestones when they conform to basic program and project objectives would help reduce borrower and lender frustration and improve DOE's credibility with the private sector.

NEED TO RESOLVE MAJOR

POLICY ISSUES

DOE has not made timely policy decisions on the use of the Federal Financing Bank (FFB) and on how to implement the interest differential payment provisions enacted by the Congress in 1978. We believe DOE should have anticipated the need to resolve these issues over a year ago.

One reason for the delay is that resolution of these issues involves complex negotiations with other Federal agencies. We believe another reason is that the administration has not clearly subordinated the goal to establish normal borrower-lender relationships to the primary program objective mandated by the 1974 act, that is, encouraging and assisting the development of geothermal energy resources. In resolving these issues, DOE should not lose sight of its primary program objective.

Need to resolve the issue

relating to use of the

Federal Financing Bank

DOE is presently considering the role FFB should play as a lender in the geothermal loan guarantee program. The FFB functions as a financial intermediary between Federal agencies and the private sector to coordinate and provide more efficient $f$ inancing of Federal and federally-assisted borrowings. The FFB can purchase the different kinds of debt and guaranteed obligations of Federal agencies and substitute its own borrowing for that of the agencies.

The FFB issue is a serious policy question that must be resolved. Use of the FFB has both advantages and disadvantages for the program. On one hand, use of the FFB lowers interest rates for the borrower. (The 1979 FFB rate has been about 9 percent.) On the other hand, it undermines the program's normal borrower-lender goal by using the Federal Government as a lender rather than the private sector.

Any decision made by DOE must be coordinated with the Department of the Treasury and OMB. Treasury has overall responsibility for FFB operations and $O M B$ has been influential in setting the course for the loan guarantee program, particularly in establishing the program's normal borrower-lender goal. 
At the time of our review, OMB and Treasury had conflicting views on the use of the FFB. OMB believed the FFB should only be used as a lender of last resort when private lenders are not available, while Treasury believed the program should be used to take into consideration Treasury's debt management practices and to take advantage of the FFB's lower financing costs. DOE favored a compromise of these positions which would give preference to the private lender but also permit use of the FFB (1) for interest differential payments (see the discussion below), (2) when the interest rates are too high in the private sector, or (3) when a lender is not available in the private sector.

In commenting on this report, OMB and DOE stated that a broad policy had been coordinated on the use of the FFB but that specific agreements detailing the policy had to be worked out. Treasury, however, did not share this opinion. Although Treasury did not provide written comments on the report, a Treasury official told us that Treasury was not aware of any coordinated broad policy.

The private financial community and borrowers need a clear indication as to when and how the FFB will be employed. Borrowers are interested because of the potential savings they might achieve due to lower interest rates; private lenders want to know the extent of FFB use in order to have a clearer picture of their future role in the program.

Need to settle issue involving interest differential payments

DOE has not defined its policy on interest differential payments. In 1978 the Congress amended the 1974 act to allow DOE to make interest differential payments to municipalities and other tax exempt entities. 1/ The payments are intended to compensate municipalities and other tax exempt entities for the additional interest they would have to pay on taxable securities issued under the guarantee program compared to the lower tax-exempt rates on bonds they would normally issue.

However, DOE has not yet resolved how interest differential payments can be made or to what extent they will be

l/Prior to this legislation, the Geothermal Loan Guarantee regulations effectively prohibited tax exempt entities from obtaining Federal loan guarantees. 
used. DOE needs to make a decision on interest differential payments in order to make the program available to municipalities or other tax-exempt entities which want to use the program. DOE told us that final resolution of how interest differential payments will be made is dependent on an Internal Revenue Service ruling which DOE has already solicited.

An application is pending which involves such payments. Although this application was received in september 1978 , a decision on this project and the amount of payments cannot be made until the interest differential policy question is resolved.

DOE has estimated that, depending on the method chosen for calculating the interest differential, and whether and how the FFB is used, payments from the Geothermal Resources Development Fund for interest differentials could be significant. For example, payments for the one pending project could total $\$ 12.2$ million over 29 years. According to DOE, this could require reserving $\$ 12.2$ million from the Fund, thus reducing the balance left to cover possible loan defaults.

\section{Recent DOE actions}

While we were preparing this final report for publication, DOE issued, on December 18,1979 , revised geothernal loan guarantee regulations. The regulations, among other things, specify criteria for loan funding through the FFB. Specifically, the FFB may be used when the guarantee requires DOE to make interest differential payments or when the interest rate and other loan agreement terms and cond $i-$ tions do not reflect the presence of a guarantee backed by the full faith and credit of the United States. Preference is to be given to funding by private lenders, especially during the project.'s construction phase. In addition, the regulations set forth the conditions under which loan guarantees will be made for otherwise tax exempt debt and provides for the payment of interest differential assistance in those cases. The regulations, however, point out that a ruling by the Internal Revenue Service is needed before DOE can make final resolution on its approach for making interest differential payments.

We believe that these actions by DOE should help the program. However, final resolution of the FFB and interest differential payments issues will only be accomplished if the revised regulations are implemented in a timely and effective manner. The cooperation of OMB, Treasury, and DOE will be needed for the implementation process to be timely and effective. 
CHAPTER 4

CONCLUSIONS, RECOMMENDATIONS, MATTERS

FOR CONSIDERATION BY THE CONGRESS, AND

AGENCY COMMENTS AND OUR EVALUATION

\section{CONCLUSIONS}

While the geothermal loan guarantee program has worked toward achieving its primary objective of encouraging and assisting geothermal energy development, progress in the first 5 years of the program's existence has been slow. Further, the program's goal to establish normal borrower-lender relationships will most likely not be met when the program's authorizing legislation is scheduled to expire in 1984. And there is uncertainty that the goal will be met within the foreseeable future. The technological and economic problems of the geothermal industry are largely responsible for this limited progress. Management problems have also contributed to the program's slow progress toward meeting its primary objective.

Despite its problems to date, the program has had value, in that, its four approved projects would not have started as early as they did without the program's support. Further, we believe the loan guarantee program may have greater opportunities to pursue its objective over the next 5 years. To take advantage of these opportunities, however, the program must be strengthened.

There are several ways DOE can improve the program. clearly, if the program is ever to meet its objective, DOE needs to develop and implement a well-defined, comprehensive program strategy. The strategy should (1) tie program activities to attainment of objectives, (2) solicit geothermal industry and financial community views and concerns with respect to the program and establish channels of communication with the private sector, and (3) provide for periodic evaluation of progress toward meeting program goals, including provision for changes when progress is not being made. For example, to speed the program toward attainment of its goal to establish normal borrower-lender relationships, the strategy should include steps which allow lenders to assume greater project administration and monitoring responsibility, thereby minimizing Government involvement. To improve project selection, specific project selection factors need to be included in the strategy. 
DOE can also improve the program in other ways. By its design the program eliminates small, non-electric projects, which may have the best chance of quickly resulting in useful geothermal energy development. DOE should explore alternative selection procedures to expedite approval of such projects and work with the Congress to develop legislation that would relax the equity requirements for such projects.

Administrative delays have plagued the loan guarantee program. DOE should ensure that further administrative delays do not occur. In this regard, DOE should ensure that regulations relating to the program are issued in a timely manner in order to fully operate the program as designed. DOE should also streamline its project selection and milestone review procedures. Redundant procedures are at least partially responsible for administrative delays in approving projects and reviewing milestones. Borrowers and lenders complain that SAN program staff lack the necessary authority to effectively speak for the Government, a factor which has harmed the program's credibility and contributed to administrative delays. DOE should delegate greater decisionmaking authority to SAN program personnel.

The actions recently taken by DOE on the FFB and interest differential payments should help the program. However, DOE needs to work closely with OMB and the Treasury to ensure timely and effective implementation of. these policies. Regarding the FFB issue, its selective use could help the program encourage and assist geothermal energy development. However, when the FFB becomes the lender under a Federal loan guarantee program, guaranteed loans are converted into direct Federal loans and are not. reflected in the budget totals. We have repeatedly held that these types of transactions be treated as "on-budget" direct loans. This would provide the Congress and others with a more complete and accurate picture of both the total scope of Federal activity and the functional allocation of Federal resources.

Regarding the interest differential payments issue, timely resolution would result in making the program available to a larger number of participants, specifically municipalities and other tax exempt entities.

RECOMMENDATIONS TO THE SECRETARY OF ENERGY

To provide clearer direction for the geothermal loan guarantee program and greater assurance that the program meets 
its primary objective and goal, we recommend that the Secretary of Energy develop and implement a comprehensive strategy. As a minimum, the strategy should include

--amendments to regulations and any other mechanisms that may be needed to allow lenders to assume greater responsibility for project administration and monitoring, thereby minimizing Government involvement;

--project selection fáctors in terms of geographical area, project type, project size, technical innovation, and borrower category;

--ways to solicit industry involvement and to seek out and select projects that best meet program needs; and

--means to evaluate program progress and to modify program activities as circumstances change.

To ensure that further administrative delays do not occur, we recommend that the Secretary take immediate action to ensure regulations are issued in a timely manner and to streamline project selection and milestone review procedures. Further, the Secretary should delegate authority to the SAN Manager to approve projects within an established ceiling and to approve restructured milestones when they conform to basic project objectives.

To ensure that the program is achieving maximum participation, we recommend that the Secretary vigorously pursue resolution of the interrelated questions on the use of FFB and interest differential payments with OMB and the Department of the Treasury.

MATTERS FOR CONSIDERATION BY THE CONGRESS

The Congress will most likely be continually faced with requests for additional loan guarantee authority and funding for the geothermal loan guarantee program. In considering both the present adequacy of support for this program and the uncertainty of the program's ability to meet its objective by its 1984 expiration date, the Congress should be mindful that the program lacks a comprehensive strategy for attaining its objective. In this connection, we are recommending that DOE develop and implement such a strategy which should 
aid in determining how additional funds will help the development and commercialization of geothermal energy most effectively. Before further authorizations are approved, the Congress may wish to require DOE to submit the strategy as part of its budgetary process, or as an addendum to any legislative proposals.

The Congress should recognize that the 25-percent equity requirement is an impediment to small geothermal users/producers participating in the geothermal loan guarantee program. The Congress may want to provide DOE authority to relax this requirement for small projects on either a case-by-case basis or reduce the equity requirement for all small business applicants. In this regard, several bills have been introduced in the 96 th Congress which would reduce the 25 -percent equity requirement for small businesses to 10 percent.

ÁGENCY COMMENTS AND OUR EVALUATION

We obtained comments on our draft report from DOE (see app. IV). OMB and Treasury did not provide written comments but did give informal comments. OMB and Treasury commented only on the issue relating to the use of FFB. These comments along with those of DOE are discussed below.

In commenting on our draft report, DOE stated it generally found the report constructive. DOE provided information that it believed would clarify or more fully explain several of the issues raised in the report.

DOE contended that even though it does not have a published program plan/strategy, it does have a comprehensive program strategy. According to DOE, this is demonstrated by its program and project priorities in the loan guarantee regulations, attendance and presentations at geothermal conferences and meetings with industry and financial community representatives, and development of an outreach program. Nevertheless, DOE stated that it will issue a written program plan/strategy in the near future. This, we believe, is a much needed action and its accomplishment should help the program move toward meeting its overall objectives. A written strategy is especially important since there are indications that the program could likely experience greater growth in the next 3 to 5 years. We hope DOE would publish this strategy as soon as possible. 
Regarding our recommendation that DOE should begin to develop regulations and other mechanisms to allow lenders to assume greater responsibility for project administration and monitoring, DOE stated that it is not appropriate at this time to allow lenders to assume greater control of projects. DOE noted that the uncertainties associated with geothermal projects demand that DOE manage the Government's financial risk through development of specific milestones and review and assessment of projects at each milestone.. DOE believes that as more geothermal activity takes place and the stateof-the-art improves, the degree of DOE's control can be relaxed and more closely approximate that in typical commercial lending.

We recognize that the present state of geothermal development may limit the extent to which lenders can immediately assume greater project control. Our recommendation, however, would require $D O E$ to plan for the time when the degree of financial risk will be reduced enough to allow private lenders to share, even if only partially or conditionally, in those risks. DOE should begin now to develop a comprehensive strategy detailing how it plans to help normalize borrowerlender relationships, including how and under what conditions it plans to allow lenders to assume greater responsibility for project administration and monitoring.

DOE stated that its recent reorganization combining technical and financial programs under one Assistant Secretary will allow for closer coordination of geothermal activities, thereby enabling DOE to apply the project selection factors recommended in our report and provide a means to evaluate overall program progress and modify activities as needed.

DOE also commented that, due to lack of sufficient applications, it has already actively promoted industry interest through presentations to interested parties and through an outreach marketing program. While this is a step in the right direction, we did not see any evidence that DOE's outreach activities either aid in the development of, or are consistent with, an overall program strategy designed to advance the program toward attaining its objective: Consequently, we believe our recommendation for DOE to develop and implement a program strategy which includes ways to solicit industry involvement and to seek out and select projects that best meet program needs is still valid.

DOE agreed with our recommendation to streamline project selection and milestone review procedures. In this regard, DOE plans to reduce processing delays by adhering to a detailed schedule with key dates for critical actions. DOE also agreed that further delegations of authority to SAN should be 
considered. DOE stated that further delegations may be considered for those circumstances where actions are of a nature that does not require headquarters involvement, or where policy issues are not involved. However, it is not clear from DOE's comments when this further delegation would take place, or if the delegation would involve authority to approve projects within an established ceiling and restructured milestones when they conform to basic project objectives, which we believe to be necessary.

DOE also provided other comments to help explain several of the issues raised by our draft report. DOE believes its level of detailed review and project control is appropriate given the inherent risks associated with uncertain technologies 1 ike geothermal energy development and has not retarded geothermal development. In this regard, DOE apparently misinterpreted our report. According to DOE, our contention that program management has served to retard the program's effectiveness is primarily based on the high level of control DOE exerts over projects. On the contrary, the program's Iimited effectiveness is primarily based on other report findings as well, including the absence of a comprehensive strategy for meeting program objectives, the failure of DOE's project selection to meet the program's highest priority needs, and the continuation of administrative delays caused by redundant project review and selection procedures.

DOE mistakenly assumed our draft report criticized DOE for the high interest rates approved for the projects in the program. Our report was not intended to be critical of DOE in this matter. In fact, the discussion of high interest rates in our draft report explained the reasons for the high rates and specifically states that the rates are tied to the prime rate, which has been extremely high in 1978 and 1979. High interest rates, regardless of their cause, have nevertheless contributed to the limited participation in the program.

DOE commented that it could have initiated a few additional geothermal activities by approving applications for exploration and resource assessment. We agree with DOE's comment that these projects do not demonstrate reasonable assurance of repayment and have a high probability of default. However, since our report did not suggest or imply that projects of this type should be approved, we do not see the relevance of this comment.

In commenting on our recommendation that the Director, $O M B$, and the secretary of the Treasury cooperate in making a timely decision on the use of FFB with the Secretary of Energy, both OMB and DOE stated that a broad policy had been coordinated on the use of FFB but that specific agreements detailing this policy had to be worked out. Treasury commented, 
however, that it was not aware of such a coordinated policy. In light of these comments and DOE's incluston of criterla for loan funding through the FFB in 1 ts revised regulations, we have dropped the specific recommendation in our draft report that the Director, OMB, and the Secretary of the Treasury cooperate in making a timely decision on the use of the FFB with the Secretary of Energy We do note, however, the need for the cooperation of OMB, Treasury, and DOE to ensure that no further delays occur relating st to the FFB issue. 


\section{STATUS OF APPROVED PROJECTS}

EAST MESA

The objective of the East Mesa project is the development of a hot-water geothermal field capable of supplying the equivalent of 29 megawatts of electricity in the Imperial Valley of California. Total cost of the project will be approximately $\$ 21$ million, of which $\$ 9.03 \mathrm{million}$ is guaranteed. Subsequent loan guarantee applications are expected for full field development and power plant construction to produce a total of 64 megawatts (gross) of electricity. In connection with this, the borrower is in the final phases of completing an agreement with a utility. which will purchase the electrical power produced by the proposed powerplant.

The East Mesa project is operated by a limited partnership between Republic Geothermal, Inc. (general partner) and Republic 1975 Geothermal Energy Drilling Program (1imited partners). The partnership submitted the East Mesa application to SAN in October 1976, which reviewed and forwarded it to headquarters in January 1977. Headquarters approved the application in May 1977.

The Bank of America is the lender. The interest $r$ ate is 120 percent of the prevailing prime rate plus 0.5 percent (18.8 percent as of December 4,1979$)$.

Milestones had been established for adequate well-flow testing, chemical analysis of the geothermal fluids, field development, and the drilling of "step-out" wells in order to estimate the size of the geothermal reservoir. DOE changed these milestones, however, to allow the project to solve technical problems encountered during the drilling.

The project encountered two significant problems: well flow-rates were 25 percent less than anticipated and (2) there was significant well-bore damage in two of the wells drilled. The borrower solved the well flow-rate problem by using downhole pumps instead of free-flowing the wells. The borrower also redrilled the damaged wells using new drilling and completion techniques, which the U.S. Geological Survey, DOE's resource consultant, believes should preclude the well-bore problem from recurring.

GEOTEERMAL FOOD PROCESSORS, INC.

The Geothermal Food Processors, Inc. (GFP) project is for the design and construction of a vegetable dehydration 
plant using the existing geothermal energy at Brady, Hot Springs, Nevada.

GFP, a Nevada corporation, operates the dehydration plant. The main product processed is onions, which are supplied under a long-term contract with a California food processor During the onion off-season. GGP intends to contract with other growers for processing other types of vegetables.

GFP submitted its original application to sAN in March 1977. Following its evaluation, SAN recommended the application for approval and forwarded it to headquarters in August 1977. In September 1977, headquarters approved the application. which amounted to a $\$ 2.8$ million guarantee for a $\$ 3.8$ million project

The project consisted of two milestones. The first included engineering plans for the plant and well testing, the second, for construction and initial plant operations.

However, the project defaulted after it could not make its first loan payment in December 1978. In our opinion, several significant problems contributed to the default. First, the plant was poorly managed, and the project was undercapitalized. Second, late equipment deliveries and technical problems forced a plant shutdown and resulted in shortening GFP's operating season. This virtually eliminated the expected revenues needed for loan payments.

Following default, DOE assumed management control of the project and restructured it.. In this connection, management was changed to include experts from the geothermal industry; a GFP equity capital investment of $\$ 450,000$ was required; and a public accounting firm was contracted to maintain accounting records. Also, plant equipment was simplified in order to avoid previous problems due, in part, to the project's technical complexity. In adition, DOE raised the loan guarantee to $\$ 3.5 \mathrm{million}$, increasing total project cost to $\$ 4.9 \mathrm{mil}-$ lion. SAN recommended the restructured project for approval in April 1979, and headquarters approved it in May 1979.

Nevada National Bank was the original lender, with the interest rate set at the prevailing prime rate, plus 2 percent. However, since the project was virtually in the operating phase at the time of restructuring, DOE helped refinance the project by securing a long-term lender through Bankers.Trust Co., at a fixed interest rate of 10.07 percent for 20 years. 
To date, GFP has contributed $\$ 1.42$ million to the project, $\$ 450,000$ of which was the capital investment required as part of the project's restructuring. Plant operations began in June 1979, and there have been no serious problems afferting plant operations.

CU-I

The objective of the CU-1 venture is to arill and flowtest exploratory hot-water wells at South Brawley, California. The development of this Imperial Valley field for electrical power production will be the objective of a subsequent loan.

The project's total cost is approximately $\$ 4$ million, of which $\$ 1.817 \mathrm{mill}$ ion is guaranteed for an outstanding period of approximately 18 months.

This project is a joint venture between McCulloch Geothermal Corp., and Geo Mac, Inc. The venture submitted its application in February 1977. Following SAN's evaluation and approval recommendation, the application was forwarded to headquarters in August 1977. ERDA headquarters approved the project in September 1977; however, the then new DOE administration also reviewed the application and gave final approval in January 1978. Additionally, the venture was slow in providing the necessary closing documents, which delayed loan closing until May 1978 .

The Bank of Montreal (California) is the lender. The interest rate is 125 percent of the prevailing prime rate, which, as of December 4, 1979, amounted to about 19 percent. The loan is expected to be refinanced at maturity with a subsequent loan for full field development at Brawley. DOE has conditionally committed funds for the subsequent loan application.

CU-1 has a total of three milestones. Basically, they include drilling and flow-testing the wells, analyzing the test data, and preparing a detailed plan for full field development.

The most significant problem encountered by $\mathrm{CU}-1$ was the collapse of a well casing during well-flow tests. However, CU-l overcame this problem by drilling through the obstruction and deepening the well after DOE approved a revision of the milestones. This revision immediately released the balance of the loan funds to cover this extra expense. The borrower has contributed additional funds to complete the project. To date, the borrower's contributions total $\$ 2.2$ million or 55 percent of total project costs. 
The venture has submitted a new loan guarantee application for $\$ 33$ million for full field development at Brawley. The California Department of Water Resources plans to construct the powerplant. DOE will decide whether to approve the project, based on its evaluation of the chemical composition of the geothermal fluids, considering its probable effect on power generating equipment.

\section{WESTMORLAND}

The goal of the Westmorland project is the exploration, development, and completion of a commercial geothermal hotwater field for the production of up to 55 megawatts (gross) of electrical power in California's Imperial Valley. The total estimated project cost is $\$ 38.8$ million, of which $\$ 29.1$ million will be guaranteed. Construction is expected to last 4 years.

The project is a joint venture of MAPCO-Geothermal, Inc., and Republic-1976 Geothermal Energy Drilling Program. The joint venture submitted its loan guarantee application in september 1977 to develop its Westmorland geothermal resource area. However, to date, there have been no operations under the program because of an extensive 21-month application evaluation and approval process in DOE. Westmorland's application underwent 10 months of milestone restructuring at SAN before it was forwarded to headquarters, recommending approval in July 1978. At headquarters, the application went through another review, before being approved in June 1979.

The Bank of America is the lender. The loan interest rate is 1 percent above the prevailing prime rate (16.25 percent as of December 4, 1979), and maturity will be in 4 or 5 years. This corresponds to the expected 4-year construction period, plus up to 1 year to obtain long-term refinancing. At maturity, the loan will be refinanced by either an acceptable private lender, or through the Federal Financing Bank.

The Westmorland project consists of six milestones. The milestones call for drilling a total of 23 wells and are structured to provide for testing and analysis throughout the development of the field.

Recognizing that Westmorland is a very risky project ( 50 percent chance of default during the first milestone), SAN's objective in restructuring the milestones was to minimize DOE's financial risk by resolving two areas of uncertainty during the first milestone: (1) verifying the validity of the project's proposed method of solving some previous well flow 
problems and (2) making an early determination of the best of two drilling areas for development.

The borrowers originally began exploratory drilling operations in 1975. To date, the borrowers have invested approximately $\$ 6.141$ million into equipment and wells that are to be a part of this project. 


\section{SPECIFIC QUESTIONS CONCERNING}

\section{ALLEGED IMPROPRIETIES}

During the course of our review, the Chairman of the Subcommittee on Energy and Power, House Comittee on Interstate and Foreign Commerce, asked us to answer certain specific questions concerning alleged improprieties in the management of two geothermal loan guarantee program projects. This appendix summarizes our responses to these questions.

\section{GEOTHERMAL FOOD PROCESSORS}

Was DOE negligence a major cause of the GFP default?

We believe DOE did not exhibit negligence in the GFP case and DOE's actions were not a proximate cause of the default. Although DOE was aware of the project's problems and took steps to rectify them, DOE was concerned that stronger action prior to default would be viewed as an intrusion into actual project management. In our opinion, the factors which caused the default--undercapitalization, poor coordination of project operations by management principals, lack of project and financial expertise, and associated late equipment deliveries and technical problems-relate more to ineffective management on the borrower's part than to DoE negligence. At most, DOE can be criticized for program staff inexperience, especially regarding the project's capitalization. (See next section below.)

Did any improprieties result from a family relationship in the GFP project?

We found no evidence that the family relationship between a GFP principal (son) and another geothermal developer (father) resulted in any improprieties. The father's company provided the lease for the land on which the project is $10-$ cated in exchange for GFP preferred stock. DOE recognized early a potential conflict of interest. To better determine GFP's equity as a result of this less than "arm's length" transaction, DOE used the historical cost to drill the existing wells ("sunk cost") instead of the preferred stock valuation. In this way DOE attempted to protect the Government's interest while still allowing the project to benefit from an opportunity to use a developed geothermal resource through a relatively inexpensive 1 and 1 ease. 
However, while we found no evidence of impropriety, we believe DOE should have recognized the weakness in the projject's capitalization. Despite its extensive selection review, DOE approved this admittedly undercapitalized prosect without requiring project equity other than sunk costs, a jondition which contributed to the project's subsequent default. DOE should have been especially careful since this sunk cost investment had been made by a company other than the borrower and was purchased with stock whose value depended on the project's eventual success. In other words, in the event of a default GFP loses very little; the Government bears the risk. SAN officials told us that they will no longer recommend approval of projects whose owner's equity consists solely of sunk costs.

\section{EAST MESA}

What portion of the East Mesa borrower's project equity is sunk costs?

The East Mesa borrower's equity contribution at the time of its loan guarantee application in October 1976 was $\$ 3.377$ million, of which $\$ 3.018 \mathrm{million}$ consisted of sunk costs. These costs represented the partnership's investments in geothermal wells and equipment at East Mesa prior to October 1976. To date, however, the partnership has increased its equity share of the project to about $\$ 9 \mathrm{mill}$ ion and, by project's end, will contribute about 57 percent of total estimated project costs.

Did the East Mesa borrower's ownership

of its own drilling company result

in any improprieties?

In our opinion, the East Mesa partnership's use of its subsidiary drilling company did not result in any improprieties. It is unlikely that the project was designed primarily to employ the subsidiary. First, the project partnership and the subsidiary were formed about the same time during 1975, about a year before DOE issued its loan guarantee program regulations and the partnership submitted its application. Second, the subsidiary drilled only about one-half of the East Mesa wells; unrelated companies drilled the others. Finally, the drilling rates charged to the project appear to be in line. DOE auditors found these rates to be lower than those the subsidiary charged unrelated projects. 


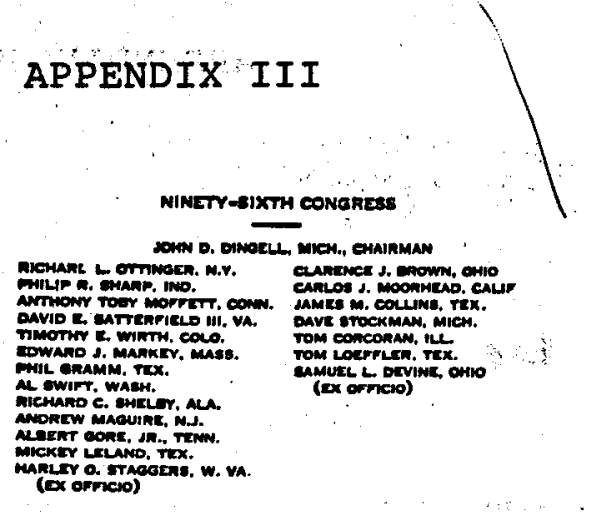

APPENDIX III

ROOM 2204

HOUSE OFFICT EUILOMN ANNEX MO. \&

NONE (202) E2:-1000

\section{CONGRESS OF THE UNITED STATES HOUSE OF REPRESENTATIVES \\ SUBCOMMITTEE ON ENERGY AND POWER}

COMMITTEE ON INTERSTATE AND FOREIGN COMMERCE

WASHINGTON, D.C. 20515

March 12, 1979

The Honorable Elmer B. Staats

Comptroller General of the United States

U. S. General Accounting office

441 G Street, N. W.

Washington, D. C. 20548

Dear Mr. Staats:

I am concerned that the geothermal loan guarantee program currently under the Resource Application Branch of the Department of Energy is not being managed as efficiently as it should be. This program has been law for several years now. With a properly administered plan, there is potential for significantly stimulating the development of geothermal energy. However, a less than well managed effort could become a classic example of wasted tax dollars.

There is reason to suspect that there may be misuse of federal funds due to a poorly organized and directed program, which may be giving support to fiscally unsound ventures. Therefore, I request that you perform a general technical, managerial and fiscal audit of the geothermal loan guarantee program. If required I would like to apply corrective action early in the developing phase of this effort.

Your attention is appreciated. please try and complete the audit by June 30,1979 . If you should have any questions please contact Roger staiger of the staff.

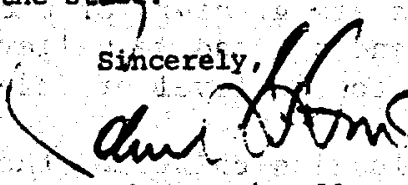

John D. Dinge 11 Chairman

JDD:Omd

THIS STATIONERY PRINTEO ON PAPER MADE WITH RECYCLED FIBEŔS 


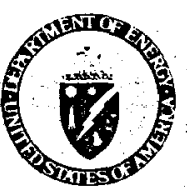

Department of Energy

Washington, D.C. 20585

DEC 111979

Mr. J. Dexter Peach, Director

Energy and Minerals Division

U.S. General Accounting Office

Washington; DC 20548

Dear Mr. Peach:

We appreciate the opportunity to review and comment on the GAO draft report entitled "The Geothermal Loan Guaranty. Program: Need for Improvements." Our views with respect to the text of the report are discussed below.

The Department has reviewed the report and finds it generally constructive. We would, however, like to offer several suggestions which we believe will clarify or more fully explain several of the issues raised by this draft report.

The report recognizes that geothermal technical and economic uncertainties are responsible for retarding the development of geothermal resources. It claims, however, that program management has further retarded development. This claim is primarily based on the careful review process and detailed project monitoring and control observed by GAO. Such requirements are greater for uncertain technologies than in normal commercial lending, and we believe the level of review and control is appropriate to. the level of Federal Government risk.

By using different evaluation criteria, the program could have initiated a few additional geothermal activities by accepting and approving applications for exploration and resource assessment. Such applications, however, do not demonstrate the reasonable assurance of repayment required by law and have an extremely high probability of default. Exploration and resource assessment are research and development activities and are more appropriately funded through grants or direct program activity rather than through the Geothermal Loan Guaranty Program.

A related criticism to lending practices is that interest rates approved for this program have been too high. This circumstance is attributed to increased lender administration costs due to additional monitoring and reporting, decreased lender control over the project, longer loan terms, lack of normal compensating balances, and uncertainty over payoff in default. Of these factors the servicing aspects do not primarily 
account for the high interest rates. Risk is the primary concern of the lenders together with structural aspects which would be present in many other loan guaranty programs. These include the degree of certainty of payoff, high administrative costs in the event of default, and high. short term construction lending rates during a period of inverted yield curves.

The report notes that large utilites may not be interested in this program because of their fear of the effect of a default on their credit rating. Almost all large projects proposed to date have been on a project finance basis. In such cases, loss on default is limited to initial investment and possibly any contractual relationship with the project. The effect beyond the loss of investment is more percelved than real, and this has been reemphasized in conversations with credit rating agencies.

With regard to the draft recomendations and the actions to be taken by DOE, the following comments are provided:

GAO Recommendation

". . that the Secretary of Energy develop and Implement a compreThensive strategy. As a minimum, the strategy should include:

--amendments to regulations and any other mechanisms that may be needed to allow lenders to assume gréater responsibility for project administration and monitoring and thereby minimizing Government Involvement;

--project selection factors in terms of geographical area, project type, project size, technical innovation, and borrower. category;

--ways to solicit industry involvement and to seek out and select projects that best meet program needs; and

- means to evaluate program progress and to modify program activities as circumstances change."

\section{DOE Comment}

Even though DOE does not have a published program plan/strategy we strongly belleve that we have a comprehensive program strategy as demonstrated by our: setting of program and project priorities in the GLGP regulations; attendance and presentations at geothermal Industry conferences; numerous presentations and constant meetings with the financial communty; and development of a formalized outreach program. In addition we will issue 
a written program plan/strategy in the near future. The report maintains that the degree to which the program is involved in project control and monitoring thwarts the program goal of developing "normal borrower-1ender relationships." However, prudent lending practices dictate that the higher the degree of project risk, the greater the need for active project monitoring, control and review.

Normal lending is typically for projects of known technology, known costs, and identifiable and manageable risks. In such projects, there is not usually a requirement to examine the results of each stage of development to determine if the initial project plan and scope needs to be restructured.

Geothermal exploration and field development is characterized by uncertainty as to water temperature, water quality and flow rates. As a field is developed, these characteristics become known and lead to altered project scope, size, and potentially the end use of the resource. It is incumbent upon the Department to manage the Government's financial risk in such projects through development of specific milestones and review and assessment of the project at each milestone.

As, more geothermal activity is developed, together with a better capability of forecasting probable field performance and characteristics, geothermal project risk will be reduced. This reduction will bring about less need for closer control of individual projects. Over time, the degree of necessary control will be relaxed and more closely approximate that in typlcal commercial lending.

It must also be noted that the Geothermal Loan Guaranty. Program is a 100 percent guaranty program in which the Federal Government assumes all of the credit risk. Under this type of program the Department, and not the lender; suffers loss in default. A partial transfer to private lenders of Departmental responsibility for close review and control can occur if lenders are willing to accept either a conditional guaranty or a partial guaranty of the loan. Under a conditional guaranty, the Department will not pay in default if technical evaluation and monitoring is not performed according to predetermined standards. Partial guaranties require that lenders share directly in loan risk. However, the degree of program risk has resulted in a lack of interest to date by private lenders to accept other than an unconditional 100 percent guaranty.

For these reasons it is not appropriate at this date to allow lenders to assume greater control of projects.

With respect for the need for project selection factors, the program regulations do establish priorities for ranking project applications. However, technical and economic risk factors have retarded the growth of the industry, and consequently program activity. To date the GLGP has received only 14 applications of which 4 were approved, 5 are pending, and 5 were not able to demonstrate reasonable assurance of repayment. 
However, DOE agrees that recent increased interest in geothermal activity due to changing tax treatment and the changing relative economics of other power sources could lead to a need to allocate avallable loan guaranty authority in the future as suggested in the draft report. To optimize achievement of overall program goals, this allocation will have to be coordinated with other geothermal activities in the Department.

The recent reorganization of DOE combining technical and financial programs under one Assistant Secretary will allow for closer coordination of geothermal activities by DOE. This will provide for development of a means to evaluate overall program progress and modify separate activities as needed. Program management will begin to develop this coordinated planning approach in the near future. This approach will address the selection factors suggested in the draft report, including geographical area, project type, project size, technical innovation and user type.

The lack of sufficient applications to require exercise of the established priorities has already caused the program to actively promote industry interest In geothermal development and the Loan Guaranty Program as recommended in the draft report. Program related activities include presentations to potential borrowers, lenders, conferences with state and local officials, presentations at industry conferences and development of an outreach marketing program.

\section{GAO Recommendation}

". that the Secretary take Immediate action to issue timely regulations and to streamline project selection and-milestone review procedures. Further, the Secretary should delegate authority to the San Francisco Operations office Manager to approve projects within an established ceiling and to approve restructured milestones when they conform to basic project objectives."

DOE Comment

The Department has followed an approval structure similar to that of private lending institutions, with the Program office serving as the business development or loan production office and the Controller's offlce serving as the credit review function. This dual process with the program negotlating with outside applicants and dealing Internaliy with a credit review function has resulted in significantly strengthened transactions. Some delays were experienced in review of early transactions. However, in the case of delays in individual transactions cited in the report, the final negotlated and approved structure of 
the transactions differed significantly from that originally proposed by the applicants.

The program management is now seeking to alleviate the problem of processing delays by adhering to a detailed schedule with key dates for critical actions. DOE has now gained substantial experien in dealing with this program and analyzing the transactions, such that review time will be accelerated.

Most geothermal projects are complex in structure and may require the + full benefit of Headquarters expertise for some time. However, DOE agrees with the recommendation that as it gains experience with this program, further delegation to the SAN office may be considered for those circumstances where actions are of a nature that does not require Headquarters involvement, or where policy issues are not involved.

\section{GAO Recommendation}

". . . that the Secretary vigorously pursue resolution of the interrelated questions on the use of the Federal Financing Bank and interest differential payments with the Office of Management and Budget and the Department of Treasury."

\section{DOE Comment}

A policy on the FFB has been coordinated with the Treasury Department and the Office of Management and Budget and is expressed in Section 790.12 of the new GLGP regulations. A specific agreement detalling this policy will be documented in a memorandum of understanding between DOE and Treasury which DOE will draft and forward to Treasury.

Final resolution of the Department's approach to interest differential assistance under this program is dependent on a ruling which we have solicited from the IRS. The approach will depend on the tax status of securities issued by normally tax exempt borrowers under this program. However, in either event the program will be able to make guaranties to municipal borrowers. Only the mechanics of payment of interest differential is affected.

We appreciate your consideration of these comments in the preparation of the final report and will be pleased to provide any additional information you may desire.

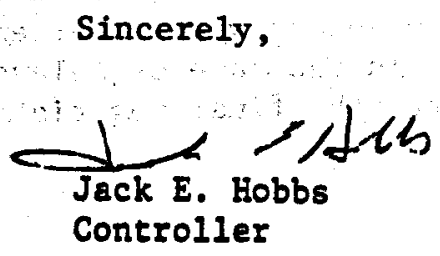

(307181) 
Single copies of $\mathrm{GAO}$ reports are available free of charge. Requests (except by Members of Congress) for additional quantities should be accompanied by payment of $\$ 1.00$ per copy.

Requests for single copies (without charge) should be sent to:

U.S. General Accounting Office Distribution Section, Room 1518 $441 \mathrm{G}$ Street, NW.

Washington, DC 20548

Requests for multiple copies should be sent with checks or money orders to:

U.S. General Accounting Office

Distribution Section

P.O. Box 1020

Washington, DC 20013

Checks or money orders should be made payable to the U.S. General Accounting Office. NOTE: Stamps or Superintendent of Documents coupons will not be accepted.

\section{PLEASE DO NOT SEND CASH}

To expedite filling your order, use the report number and date in the lower right corner of the front cover.

GAO reports are now available on microfiche. If such copies will meet your needs, be sure to specify that you want microfiche copies. 
AN EQUAL OPPORTUNITY EMPLOYER

UNITED STATES

GENERAL ACCOUNTING OFFICE

WASHINGTON, D.C. 20548

OFFICUL BUSTESS

PENALTY FOR PRTVATE USE, 2300
pOSTAGE AND TEES PAIO

U. S. GENERAL ACCOUNTING OFTICE

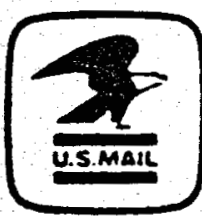

THIRD CLASS

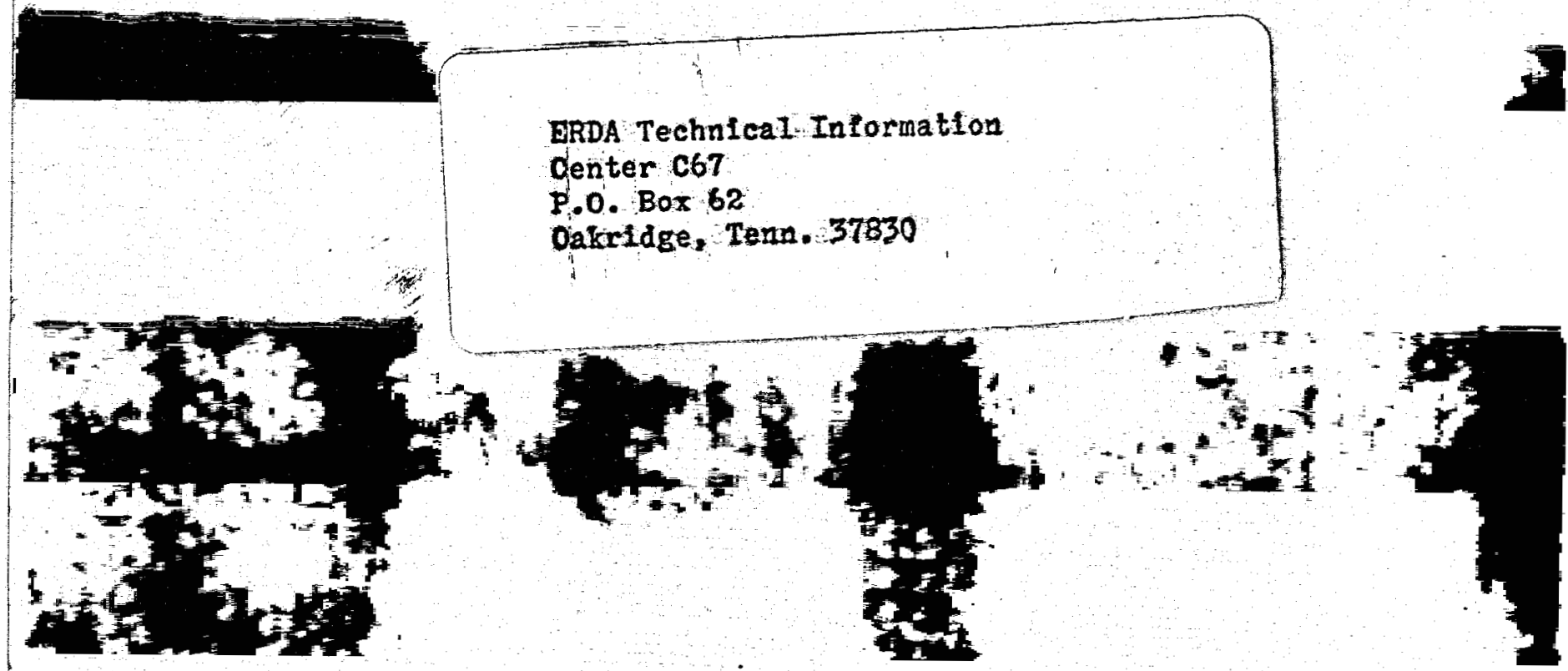

